EEŚTI NŚV TEADUSTE AKADEEMIA TOIMETISED. V KÖIDE

BIOLOOGILINE SEERIA, 1956, NR. 3

ИЗВЕСТИЯ АКАДЕМИИ НАУК ЭСТОНСКОЙ ССР. ТОМ V

СЕРИЯ БИОЛОГИЧЕСКАЯ. 1956, 스 3

\title{
LAGERABADE METSASTAMISE PROBLEEMIST
}

\author{
U. VALK, \\ bioloogiateaduste kandidaat
}

Nõukogude Liidu loodeosa, kuhu kuulub ka meie liiduvabariik, on üheks - suurima soostumisega alaks Euroopas. Nii on Leningradi oblastis soid $18 \%$, Karjala-Soomes 26\% (Zaitsev, 1954), Eesti NSV pindalast on kaetud soodega umbes $17 \%$ (Varep, 1953). Mida kaugemale põhja poole, seda enam suureneb soode hulgas, mis teatavasti jaotatakse madalsoodeks, siirdesoodeks ja rabadeks, rabade osatähtsus. Smolenski oblastis on soode pindalast rabasid $46 \%$, Kalinini oblastis $65 \%$, Leningradi oblastis $68 \%$, Karjala-Soomes 68\% (Dokukin, 1939). Arvestades Eesti geograafilist asendit võib arvata, et kolmandik kuni pooled Eesti soodest kuuluvad rabade hulka.

Valatamata rabade laialdasele levikule on nad seni rahviamajanduses leidnud vähest kasutamist. Paljude sajandite jooksul on küll valitsenud püüd intensiivistada rabade kasutamist, võttes rabad kasutusele põllu-, harvem metsamalana, kuid tulemused jäid juhuslikeks. Juba 16. sajandist leidub üksikuid kirjalikke märkmeid soode, nende hulgas ka rabade põllumajandusliku kasutamise kohta. Sellest ajast pärinevates märkmetes räägitakse ülepõletatud soodel tatra kasvatamisest. Juba ühes 1583. laastast säilinud ürikus kirjeldatakse sellist sookasutamișe viisi vana viisina (Seelhorst, 1914).

Usaldusväärsemaid andmeid soode kuivendamise ja ülepõletamise kohta nende põllumajandusliku kasutamise eesmärgil leidub 17. sajandi kirjanduses, kus kirjeldatakse soode sellist kasutamist Hollandis (Heuser, 1927), Soomes, Karjalas (Guleitšik, 1954), Austrias ja Saksamaal. Uks silmapaistvamaid sooteadlasi B. Tacke (1929) märgib Põhja-Saksamaa rabade kohta, et neid on kasutatud põletuskultuuri teel juba ligi 200 laastat. Ulepõletatud, mõõdukalt kuivendatud rabasid kasutati põllumajanduses pärast ülepõletamist kuni $6-7$ alastat, mille järel raba jäeti üheks inimeaks seisma ning alles siis võeti eelkirjeldatud viisil uuesti kasutusele. Arvates 19. sajandist tuuakse rabade põletuskultuuri kohta juba vastuväiteid ja juhitakse ikka enam tähelepanu rabade otstarbekohasele kuivendamisele, maaharimisele, lubjastamisele ja väetamisele, kusjuures rabasid hakatakse kasutama põllumajandusliku maana aastast aastasse ilma nn. puhkeajata. Enam-vähem tulemuskindlad võtted lagerabade põllumajanduslikuks kasutamiseks on suudetud välja töötada aastasadade jooksul omandatud kogemuste põhjal alles viimaseil aastakümneil. Seevastu lagerabade metsamajandusliku kasutamise kohta üldistamiskõlblikke kogemusi pole meil teada. 
Missugused on siis need põhjused, rabade kasvukoha iseärasused, mis raskendavad rabade kasutamist taimekasvatuses? Peatume lühidalt eelkõige neil küsimustel. Tugineme sel puhul peale kirjanduses leiduvate andmete ka meie poolt laastail 1952-1955 teostatud uurimiste tulemustele, mis on saadud Tallinna lähedal asuvalt, lagerabade hulka kuuluvalt Rae rabalt, kuhu on rajamisel, osalt ka juba rajatud katsed raba metsastamisvõimaluste selgitamiseks.

Rabaosa, kuhu katsed rajati, on liival asuva kuni $5 \mathrm{~m}$ tüseduse turbalademega. Peal-asuv turbalade moodustub mitme meetri tüsedusest halvasti lagunenud sfagnumturbast. Taimkattes domineerivad kanarbik $(50-60 \%$ katteväärtusest) ja Sphagnum acutifolium (15-20\% katteväärtusest); neile lisanduvad Rubus chaememorus, Eriophorum vaginatum, Oxycoccus quadripetalus, Aulacomnium palustre jt. Aastakümnete eest on see järvelise tekkega raba tõenäoliselt põlenud, millele viitavad mõned rabal esinevad taimed kui ka raba suhteliselt nõrk mätlikkus.

Rae raba metsa kasvu kahjustab siin valitsev hüdroloogiline režiim. Tingituna rabaturba füüsikalistest omadustest ja raba vegetatsioonist, on «pōhjavesi», mida õigem on nimetada pinnaseveeks (rabaveeks), laasta läbi maapinna lähedane, langedes sügavamale vaid põuaperioodil. 1954/55. aasta mõotmised näitasid, et Rae rabal püsis pinnasevesi sügis- ja talvekuudel (septembrist märtsini) kuukeskmisena ca 5-20 cm sügavusel, sõltudes raba külmumisest, kuna kevad- ja suvekuudel kõikus, sõltuvalt sademetest, 3-60 cm-ni (tabel 1).

Tabel 1

Pinnasevee keskmine sügavus Rae rabal sentimeetrites

\begin{tabular}{l|c|c|c|c|c|c|c|c|c|c|c|c|c}
\hline & \multicolumn{3}{|c|}{ 1954. a. } & & & & & 1955. a. & & \\
VII & VIII & IX & X & XI & XII & I & II & III & IV & V & VI & VII & VIII \\
\hline 36 & 7 & 16 & 8 & 6 & 8 & 13 & 6 & 21 & 22 & 3 & 26 & 42 & 60
\end{tabular}

Viimane äärmustulemus $(60 \mathrm{~cm})$ fikseeriti põuasel suvel - 1955. a. augustis. Ka sellise sügava pinnasevee seisu juures ei kaotanud pindmine turbakiht vett täielikult, mis põhiliselt seletub sfagnumturba suure veehoidmisvõimega, osalt ka kuiva turba võimega imeda enesesse õhust veeauru. Turba veesisaldust sügava pinnasevee seisu juures näitab tabel 2 .

Metsasektoris tehtud katsed näitasid, et männi- ja kuusetõusmed turbas . (mille lagunemisaste oli $45 \%$ ) närbusid siis, kui turba niiskus, arvestatuna täielikust veemahutavusest, langes lalla $10 \%$. Samuti näitasid katsed, et mida vähem lagunenud on turvas, seda madalam on närbumisniiskus. Seepärast on tõenäoline, et ka sügava pinnaseveeseisu juures rabal turba niiskus ei lange piirini, mis ohustaks puude kasvu, ja et rabade ülekuivendamise oht nende kasutuselevõtu korral taimekasvatuses ei ole tõenäoline ka väga intensiivse kuivendamise juures.

Küll aga oli puude kasvuks ebasoodne ajavahemik, mil pinnasevesi püsis maapinna lähedal. Teatavasti toitainetevaene happeline pinnasevesi (Rae raba pinnasevee $\mathrm{pH}$ on $4,8-5,5$ ) ei sisalda hapnikku, mis puude kasvuks on ilmtingimata vajalik. Hapniku puudumist pinnasevees kinnitasid ka meie analüüsid. 
Turba happesus ja turba niiskus Rae rabal $86 \mathrm{~cm}$ sügavuse pinnasevee seisu juures

\begin{tabular}{|c|c|c|c|c|}
\hline \multirow{2}{*}{$\begin{array}{c}\text { Turbakihi sügavus } \\
\text { cm-tes }\end{array}$} & \multirow{2}{*}{$\begin{array}{l}\text { Turba } \\
\mathrm{pH}\end{array}$} & \multicolumn{3}{|c|}{ Niiskuse $\%$} \\
\hline & & $\begin{array}{l}\text { esialgsest } \\
\text { kaalust }\end{array}$ & $\begin{array}{l}\text { absoluutkui- } \\
\text { vast kaalust }\end{array}$ & $\begin{array}{l}\text { täielikust vee- } \\
\text { mahutavusest }\end{array}$ \\
\hline $\begin{array}{c}0-2 \\
10 \\
20 \\
30 \\
40 \\
50 \\
60 \\
70 \\
80\end{array}$ & $\begin{array}{l}2,98 \\
2,69 \\
2,71 \\
2,65 \\
2,67 \\
2,72 \\
2,70 \\
2,55 \\
2,32\end{array}$ & $\begin{array}{l}83,13 \\
86,68 \\
87,16 \\
88,66 \\
88,68 \\
90,92 \\
91,25 \\
91,31 \\
91,76\end{array}$ & $\begin{array}{r}493 \\
649 \\
679 \\
770 \\
784 \\
1000 \\
1043 \\
1059 \\
1122\end{array}$ & $\begin{array}{l}27,87 \\
36,58 \\
38,33 \\
43,40 \\
47,22 \\
56,37 \\
58,79 \\
59,69 \\
63,25\end{array}$ \\
\hline
\end{tabular}

Märkus. Proovid vōeti kraavist $5 \mathrm{~m}$ kauguselt. $\mathrm{pH}$ määrati absoluutselt kuiva turba $\mathrm{KCl}$ leotisest elektromeetriliselt.

Tingituna sellest, et puujuured taluvad hapniku puudumist vaid lühikest aega ega suuda elutseda seetõttu ka raba pinnasevees, on rabades puude juurekava pindmine. Kirjeldades rabamändi, märgib akadeemik V. N. Sukatšov (1926), et rabamänni juurekava ei suuda tungida sügavamale kui pool meetrit. Kui aga juured jäävad turbasambla pealekasvamisel sügavamale, männid kas surevad või jäävad tugevasti kinatsema.

Puude puudumist või kiratsemist rabal põhjustavad peale ebasoodsa hüdroloogilise režiimi ka teised tegurid, mille hulgas on oluline koht rabaturba madalal toitainetesisaldusel. Et puude puudumine on põhjustatud rabaturba madalast toitainetesisaldusest, seda kinnitavad veenvalt raba metsastamiskatsed Rootsis (Malmström, 1952).

Turvasmuldade toitainetesisaldust iseloomustab suurel määral nende tuhasisaldus (mineraalainetesisaldus). Rabaturba tuhasisaldus ei tõuse tavaliselt üle $5 \%$. Rae rabal kuni $10 \mathrm{~cm}$ sügavusel fikseeriti tuhasisaldus $3,0-5,0 \%$ ja $10-20 \mathrm{~cm}$ sügavusel $2,0-4,0 \%$. Rabaturba keemilised analüüsid näitavad, et rabas on puudus kaaliumist, fosforist, lubjast ja taimedele kättesaadavast lämmastikust. Andmed lämmastiku, fosfori, kaaliumi ja lubja sisalduse kohta rabaturbas tuuakse tabelis 3 .

Tabel 3

$\mathrm{N}, \mathrm{P}_{2} \mathrm{O}_{5}, \mathrm{~K}_{2} \mathrm{O}$ ja $\mathrm{CaO}$ sisaldus rabaturbas protsentides absoluutkuivast kaalust

\begin{tabular}{l|c|c|c|c}
\hline Kelle andmetel & $\mathrm{N}$ & $\mathrm{P}_{2} \mathrm{O}_{5}$ & $\mathrm{~K}_{2} \mathrm{O}$ & $\mathrm{CaO}$ \\
\hline Rae raba & $0,6-1,7$ & $0,08-0,10$ & $0,04-0,07$ & $0,48-0,57$ \\
Pjavtšenko (1954) & $1,0-2,0$ & $0,10-0,25$ & $0,04-0,08$ & $0,30-0,48$ \\
Kostjakov (1951) & $0,8-1,2$ & $0,05-0,15$ & $0,04-0,06$ & $<0,5$ \\
Bahhulin (1949) & $0,8-1,2$ & $0,06-0,12$ & kuni 0,1 & kuni 0,5 \\
Nemtšinov (1953) & $0,55-1,75$ & $0,03-0,12$ & $0,03-0,08$ & $0,17-0,56$ \\
Garkuša (1947) & 1,0 & 0,1 & 0,02 & 0,4 \\
Becker-Dillingen & 1,30 & 0,08 & 0,05 & 0,23 \\
$\quad$ (1939) & 0,9 & 0,10 & 0,04 & - \\
Guleitšik (1954) & 1,81 & 0,16 & 0,04 & 0,29 \\
Sukatšov Gully järgi \\
(1926)
\end{tabular}


Tabelis toodud mineraalainetest on taimedele omastatav vaid osa, mis suurel määral sõltub rabaturba halvast lagunemisest. Turba lagunemist pidurdab rabaturbas mitteküllaldane mikroorganismide ja mullafauna tegevus. Seda põhjustavad omakorda liigniiskus, mineraalainevaesus, hapniku puudumine, ebasoodne mikrokliima ja vee ning turba tugevasti happeline reaktsioon (Bülov, 1929; Franz, -1950). Viimane, kõikudes tavaliselt 3-4 ümber (Rae raba $\mathrm{pH}$ on 2,3-3,4), ongi üks põhitegureid, mis pidurdab rabaturba lagunemist. Tugevasti happeline reaktsioon, mis on põhjustatud happeliste laguproduktide kogunemisest, on iseloomulik mitte üksnes pinnase pealiskihile, nagu seda näeme leetmuldadel, vaid ka sügavamatele kihtidele (tabel 2).

Rabapinnase tugeval happesusel on suur tähtsus turbasammaldele, mis kuuluvad atsidofiilsete, s. t. happeliste muldadega kohanenud taimede hulka. Happelise keskkonna neutraliseerimisel (näit. pinnase lubjastamisel) hukkuvad turbasamblad (Sukatšov, 1926). Viimast asjaolu tuleb raba põlluja metsakasvatuslikul kasutuselevõtmisel kindlasti arvestada, sest turbasammaldel on rabas taimekasvuks ebasoodsate tegurite kujundamisel määrav osia.

Mis puutub valitsevasse mikrokliimasse, on see, nagu näitasid meie uurimised, taimekasvuks küll ebasoodne, kuid ei ole sedavõrd äärmuslik, et teeks raba põllu- ja metsamajandusliku kasutamise võimatuks.

Rabal esinevad äärmustemperatuurid, mis on kõige ekstreemsemad maapinnal, võivad küll vegetatsiooniperioodil tõusta päeval lühemaks ajaks üle $50^{\circ} \mathrm{C}$ ja öösel langeda alla $0^{\circ} \mathrm{C}$, kuid nad ei kujune ebasoodsamaks kui nõmmedel (Valk, 1953) või siirdesoometsade raiestikel (Kollist, 1953), milliste metsastamine võib anda (vaatamata taimekasvuks ebasoodsatele äärmustemperatuuridele) häid tulemusi.

Ka teised meteoroloogilised näitajad - õhutemperatuur, õhuniiskus, pinnase temperatuur, samuti pinnase külmumine võimaldavad raba kasutuselevõtmist taimekasvatuses, kuigi neist kaks viimast pōhjustavad rabal taimekasvuks märgatavalt halvemaid tingimusi kui mineraalmuldadel. Nimelt tingituna turbasambla ja sellest moodustunud vähelagunenud turba halvast soojusjuhtivusest (Sukatšov, 1926; Anikijev, Obuhhova jt. 1951), püsib kelts rabal (võrreldes mineraalmuldadega) kauem. Mõnel aastal (näit. 1954. a.), kui Rae raba, tingituna vähese lumega talvest, külmus kohati kuni $0,5 \mathrm{~m}$ sügavuselt, püsis kelts kuni maikuu lõpuni. Keltsast põhjustatuna jääb rabapinnas kevadel kauem külmaks, mistõttu taimekasvu periood algab siin hiljem kui mineraalmuldadel. Samuti lõpeb sügisel taimekasvu periood rabal viarem. Eeltoodu põhjustab rabal võrreldes mineraalmullaga mõnevõrra lühemat vegetatsiooniperioodi.

Niisiis tuleb raba põllu- ja metsamajanduslikul kasutuselevõtmisel arvestada järgmisi põhilisi, rabale spetsiifilisi tegureid: mineralalainevaest, suure veemahutavusega sfagnumturvast ja selle pidevat pealekasvamist, toitainerikka põhjlavee puudumist, liigniiskust, hapniku puudumist pinnasevees, rabapinnase suurt happesust, spetsiifilist taimestikku, loomastikku ja mikrokliimat. Tuleb larvestada ka asjaolu, et kõigi nende kasvukoha komponentide viahel valitsevad väga keerulised vastastikused suhted.

Lagerabade taimekasvatuslik kasutuselevõtmine on mõeldav ainult siis, kui rabal valitsevad kasvukohatingimused põhjalikult muudetakse taimekasvule soodsamaks. Et see on võimalik, seda kinnitavad raba põllumajiandusliku kasutamise kogemused. Erivõtetega (kuivendamine, väetamine, lubjastamine jt.) on võimalik rabal kasvatada küllalt tähelepanuväärseid saake. Kostivere sovhoosis, kus raba kasutatakse põllumaana praegu ligi 80 ha ulatuses, saadakse 1 ha-lt tenaks kasvatatud rukist $14-20$ tsentnerit, ristikut 40 tsentnerit, haljasmassiks kasvatatud rukist $80-120$ tsentnerit ja 
segatist 120-140 tsentnerit. Veelgi suuremaid ja kindlamaid saake saadakse Saksamaal, kus rabakultuuridega on pikaajalisi kogemusi (Brüne, 1952).

Pikaajaline põllukultuuride kasvatamine muudab aja jooksul künnikihi ulatuses endise rabapinnase põhjalikult. Aktiivsemaks muutunud mikrobioloogilise tegevuse tõttu turvas kõduneb, turbas suureneb mineraalainetesisaldus, sealhulgas ka taimede poolt omastatavate ühendite (esijoones lämmastiku, kaaliumi, fosforühendite ja lubja) hulk, mille tulemuseks on turbaviljakuse tõus (Lupinovitš, Golub, 1952; Nemtšinov', 1953; Beljakova, 1954; Kozlov, 1955). Rabade põllumajandusliku pikaajalise kasutamise tulemusena kujunevad siin uued tingimused, mis loovad rabal eeldusi ka metsa kasvuks. Nagu näitavad Zooloogia ja Botaanika Instituudi metsasektori töötajate tähelepanekud Kaliningradi oblastist, on endised põllumajanduses kasutusel olnud rabad kattunud looduslikul teel kasemetsaga, mille kasv on seni (10-15 aasta vanuseni) rahuldav. Kuidas arenevad need praegu veel noored puistud vanemas eas, selle kohta puuduvad kogemused.

Kahjuks osutub lagerabade metsastamine sel viisil keerukaks ja kulukaks, mistõttu Zooloogia ja Botaanika Instituudi metsasektoris püüti raba metsastamiseks leida teisi, lihtsamaid ja ökonoomsemaid võtteid.

Lagerabade metsastamisviiside otsinguil lähtuti sellest, et rabasid ei ole võimalik metsastada enne, kui neil on loodud taimekasvuks soodne hüdroloogiline režiim, kui on tõstetưd rabapinnases toitainetesisaldust, kindlustades ühtlasi selle püsimist ilma raba iga-aastase väetamiseta, ja kui rabal orgaanilise massi (eriti turbasammalde) kiiret pealekasvamist on pidurdatud.

Selle eesmärgi saavutamiseks kontrolliti metsakasviatuslikel eesmärkidel nii rabade põllumajanduslikul kasutamisel rakendatavate mõnede agrotehniliste võtete otstarbekust (kuivendamine, rabade põletamine, väetamine, nabapinnase happesuse vähendamine) kui ka välismaal rabade metsastamisel saadud mõningaid kogemusi.

Alljärgnevas peatutakse lühidalt uurimistulemustel, mis väga jämedates joontes selgitavad rabade metsastamise võimalusi.

Liigniiskuse all kannatavate maade metsastamisel või neil kasvava metsa tootlikkuse suurendamiseks on ainsaks üldtuntud labinõuks olnud pinnase kuivendamine. Seepärast on arusaadav, miks rabade metsastamisküsimust on püütud lahendada üksnes kuivendamisega.

Selle kohta, et raba metsastamiseks piisab üksnes tavalisest kuivendamisest, leidub viiteid kirjanduses (Sukatšov, 1926; Karu, 1938; Markus, 1940; Pjavtšenko, 1954). Kuid nende viidete üldistamisse tuleb suhtuda kõige suurema ettevaatlikkusega, sest on pöhjust arvata, et nimetatud juhtudel ei olnud tegemist mitte sügavaturbaliste lagerabadega, missuguste metsastamist käsitleb käesolev artikkel, vaid turbamaadega, mis on kaetud mineraalmaal või viljakamal turbakihil asuva õhema sfagnumturbakihi ja sellele kasvava rabataimestikuga või siis rabadega, kus valitseb erandlik hüdroloogiline režiim.

Et tüüpiliste tüseda sfagnumturbalasundiga rabade metsastamiseks ei piisa raba tavalisest kuivendamisest, seda näitas juba G. I. Tanfiljev, üks esimesi sooteadlasi. Tanfiljev (1895) märgib, et kraavitamine ei pōhjusta rabas olulisi muutusi; pinnasevesi alaneb vaid kraavi vahetus läheduses, kus mõnevõrra paraneb männi kasv ja ilmub kask. Kuid juba veidi knaavist kaugemal säilitavad männid endise kidura ilme, samuti arenevad siin endiselt rabataimed ega asendu rikkalikuma taimestikuga. Eelnimetatud kasvupilti näeme ka meil rabades, mida läbivad kraavid. Näiteks Toomal, juba pikemat aega kuivendatud rabas on enamik mände endiselt kidura- 
ilmelised isegi kraavi läheduses. Veelgi ilmekamaid näiteid selle kohta, et raba metsastamiseks ei piisa üksnes kuivendamisest, toob C. Malmström (1952).

Öelduga ei taheta sugugi vähendada kuivendamise tähtsust rabade metsastamisel, vaid juhitakse tähelepanu sellele, et koos kuivendamisega tuleb rabade metsastamiseks rakendada ka teisi abinõusid ja et tingituna rabaturba suurest veehoidmise võimest peab rabadesse rajatud kuivendusvõrk olema tihe. Intensiivse kuivendamise vajalikkust näitavad mitmed uurimused. A. D. Dubach (1945) jälgides samblaturbas vee läbivust, leidis, et rabas põhjavesi langeb järsult kraavi ääres ja et kraavi mõju ulatub 20-30 m kaugusele. V. Gorjatškini andmeil ulatub kraavi mõju sfagnumturbaga aladel vaid $6 \mathrm{~m}$-ni (Vilenski, 1954). Meie uurimised Rae rabal näitasid, et kuivendamise mõju ulatus kraavist 8-10 m-ni (joon. 1).

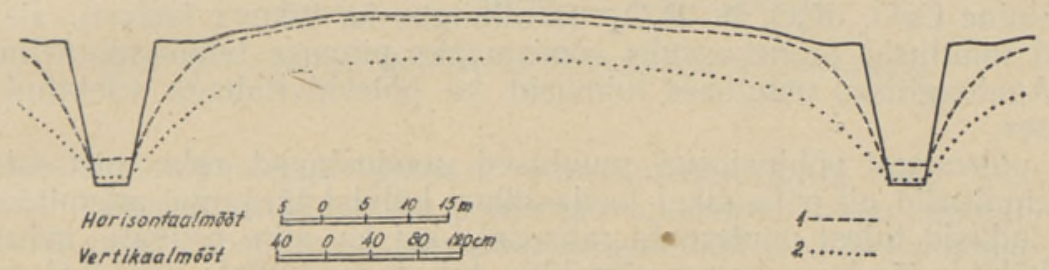

Joonis 1. Kraavitamise mõju Rae rabal pinnasevee sügavusele. 1 - depressioonikōver küllaldase niiskusega perioodil (1955. a. maikuu keskmine) ja 2 - sademetevaesel perioodil (1955. a. juulikuu keskmine).

Eeltoodust saab mõistetavaks, miks rabade kuivendamine tavalises korras ei tule arvesse, vaid selleks tuleb otsida eri võtteid.

Nagu näitavad Inglismaal teostatud rabade metsastamiskatsed, on kõige otstarbekam selleks rajada tavalistesse kraavidesse suubuvad väikesed, kas käsitsi või spetsiaalsete atradega valmistatud kraavid. Lähtudes ökonoomsusest on labidatöö korral kraavikeste sobivaks laiuseks ja sügavuseks 35$40 \mathrm{~cm}$ ning vahekauguseks 4-6 m (Zehetmayr, 1953). Loomulikult tuleb kraave seoses vajumisega aeg-ajalt süvendada. Selle vajalikkust kinnitasid meie vaatlused Rae rabal, kus nelja kuivendusjärgse aasta jooksul turvas vajus kraavi vahetus läheduses $30-35 \mathrm{~cm}$, mistõttu kraavide sügavus vähenes $150 \mathrm{~cm}-1 \mathrm{t} 115-120 \mathrm{~cm}-n i$.

Alles sellise kuivendamise tulemusena, kus metsastamisele kuuluv rabaosa tervikuna on kuivendamise mõju piirkonnas, luuakse eeldused rabade metsastamiseks. Kuivendamisest põhjustatuna kujuneviad soodsamad tingimused pinnase õhustavuseks, orgaanilise aine lagunemiseks ja nitrifikatsiooniks (Lupinovitš, Golub, 1952; Guleitšik, 1954), mida põhjustab omakorda mikroorganismide tegevuse suurenemine turbas (Multamäki, 1952; Kozlov, 1955).

Samuti tingituna kuivendamisest, mida kinnitasid meie vaatlused, külmub raba talvel mõnevõrra sügavamalt ja sulab kevadel varem. Esimene on oluline seetõttu, et turvasmuldade külmumine, nagu märgivad I. S. Lupinovitš ja T. F. Golub (1952), tõstab nende viljakust, kuna teisest lasjaolust põhjustatuna pikeneb rabal vegetatsiooniperiood.

Need kuivendamisest põhjustatud muutused kajastuvad ka raba taimkatte muutumises. Rae rabal seisnesid need mõnede rabataimede katteväärtuse ja vitaalsuse suurenemises või vähenemises, kuna uusi liike rabale kuivendamise tulemusena ei ilmunud. Rae rabal vähenes kuivendamise tulemusena katteväärtus kõige silmapaistvamalt turbasammaldel ja suurenes 
kanarbikul. Samuti muutus kasvupilt kanarbikust, mis - olles raba kuivendamata osal kidur, keskmise kõrgusega $12-20 \mathrm{~cm}$ - saavutas kuivendamise mõju piirkonnas (6 m kraavist) keskmiseks kõrguseks 20$40 \mathrm{~cm}$. Kuna meie tähelepanekud kanarbikuga kaetud kehvadelt mineraalmuldadelt näitaviad, et koos puude kasvutingimuste paranemisega suureneb kanarbiku vitaalsus, siis on pōhjust selle oletamiseks ka rabal.

Kuid lagedate rabade metsastamiseks ei piisa üksnes kuivendamisest, vaid tuleb kasutada ka teisi võtteid, mis tõstavad rabapinnase viljakust.

Uneks selliseks võtteks rabade esmakordsel kasutuselevõtmisel on rabade ülepõletamine, mis tasandades rabapinnast hõlbustab maaharimist ja parendab mulla füüsikalis-keemilisi omadusi (Seelhorst, 1914; Heuser, 1927; Dokturovski, 1935; Turnas, 1936). Rae raba nõrgalt ülepõletatud osal, kus põles taimkate koos mõnesentimeetrise turbakihiga, tõusis esimesel aastal kuni $15 \mathrm{~cm}$ tüseduses turbakihis mõnevōrra tuhasus ja koos sellega üldine $\mathrm{CaO}, \mathrm{K}_{2} \mathrm{O}$ ja $\mathrm{P}_{2} \mathrm{O}_{4}$ (sealhulgas ka liikuva fosfori) sisaldus; samuti muutusid taimekasvuks soodsamaks pinnase temperatuuritingimused. Analoogilised muutused toimusid ka põlevkivituhaga väetatud rabapinnases.

Et põlemisest põhjustatud muutused soodustavad raba metsastumist, seda kinnitasid nii põlendikul looduslikust külvist tärganud männitõusmed, mis puudusid tulest puutumata rabaosal, kui ka siin asuvate männi- ja kuusekülvide jõudsam areng võrreldes tulest puutumata rabaosal asuvate samaealiste männi- ja kuusekülvidega. Kuid nagu võib järeldada samas tehtud vaatlustest, kaob põletamise soodustav mõju kasvukohatingimustele ning seega ka puutaimede arenemisele tõenäoliselt $3-4$ aasta jooksul, mida võib seletada ühelt poolt tuhkainete väljauhtumisega (Rae rabal oli juba teisel põlemisjärgsel aastal vähenenud poole võrra $\mathrm{K}_{2} \mathrm{O}$ ja $\mathrm{P}_{2} \mathrm{O}_{5}$ sisaldus, olles ligikaudu niisama suur kui enne pôlemist; märgatavalt oli kahanenud ka $\mathrm{CaO}$ sisaldus) ja teiselt poolt taimkatte osalise taastumisega. Viimase taastumisel oli põlendikul silmapaistvaks turbasammalde katteväärtuse langus, sest larvestades kanarbiku jõudsat uuenemist, võib arvata, et juba lähemail aastail tõuseb tunduvalt kanarbiku katteväärtus.

Kuna rabataimestik ei soodusta raba metsastamist, vaid on puutaimedele pigem konkurendiks toitainete tarvitajana, tuleb rabade metsastamiseks leida viise, mis vähendaksid kuivendatud ja ülepõletatud rabaosal taimkatte taastumist ning tagaksid rabapinnases viljakuse tõusu.

Selliste võtete hulka kuulub metsakultiveerimisel peaaegu alati kasutatav agrotehniline võte - maapinna ettevalmistamine.

Nagu näitavad Inglismaal rabade metsastamisviiside otsinguil saadud kogemused (Zehetmayr, 1935; Guillebaud, 1938; Macdonald, 1951), osutub otstarbekohaseks maapind metsakultiveerimiseks valmistada ette samaaegselt kuivendusvõrgu rajamisega.

Maapinna ettevalmistamist on soovitav teostada mehhaniseeritult, kasutades selliseid atru, mis valmistavad samaaegselt kuivenduskraaviga ca 20-30 cm kõrguse peenra (Zehetmayer, 1953). Kirjeldatut on võimalik sooritada ka labida abil käsitsi. Selleks asetatakse kraavidest väljakaevatud turvas nii, et see moodustaks eelkirjeldatud peenra.

Kui peenraid ei saa nende valmistamise järel tugevasti kinni rullida, jäetakse nad maapinnaga liitumiseks seisma kaheks-kolmeks ja mõnikord isegi enamaks laastaks. Maapinnaga liitumata peenrad võivad nii tugevasti läbi kuivada, et neil kultuurid hukkuvad (Guillebaud, 1938).

Uks pinnase ettevalmistamise variantidest on kujutatud skemaatiliselt joonisel 2. Mõeldav on rabapinnase ettevalmistamine ka suuremate küngastena, millist viisi on kasutatud samuti Inglismaal.

Maapinna selline ettevalmistus parandab rabal üheaegselt pinnasevee 


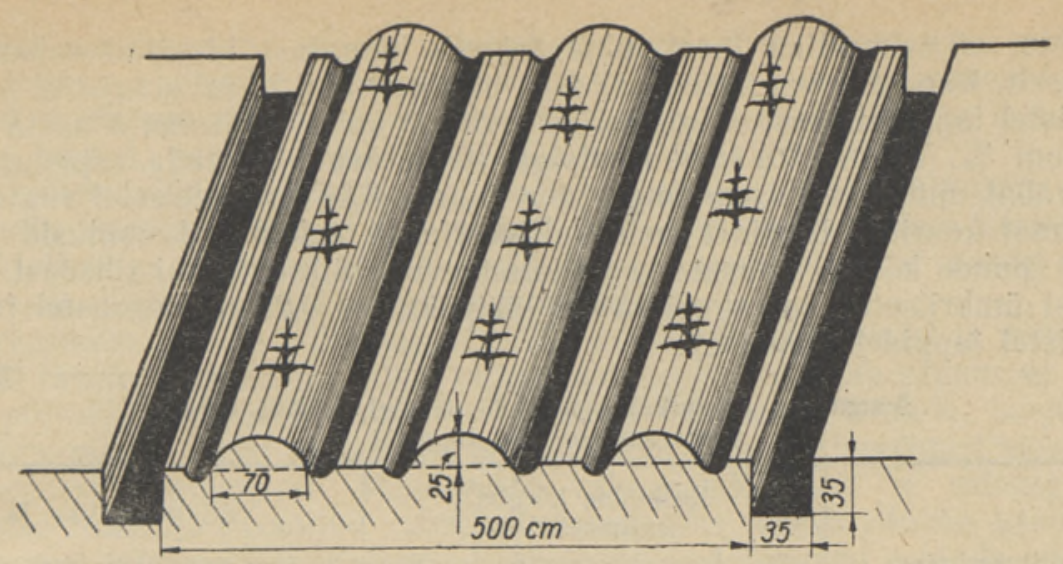

Joon. 2. Metsakultiveerimiseks ettevalmistatud rabapinnas.

sügavuse reguleerimisega pinnase õhustamistingimusi ning kõrvaldab taimkatte. Viimase eemaldamine põhjustab omakorda, nagu näitasid meie uurimised, suvel rabapinnase suuremat soojenemist jia talvel pinnase sügavamat läbikülmumist. Taimkatteta rabaosade sügavam läbikülmumine ilmnes eriti selgesti lumikatte puudumisel. 1954. a. lumevaesel talvel külmus pinnas, kus taimkate oli kôrvaldatud, ligi $10 \mathrm{~cm}$ sügavamalt (joon. 3).

Lisaks sellele, et rabapinnase ettevalmistamine parandab puude kasvu kaudselt rabapinnases toimunud soodsate muutuste tõttu, mis tõstavad rabaturba viljakust, loob pinnase ettevalmistamine paremad tingimused puude toitumiseks ka otseselt, sest ettevalmistatud pinnasel väheneb tunduvalt taimestiku osa toitesoolade tarvitajana. See asjaolu saab kaaluvaks

Ettevalmistamata pinnas

Kamarast kooritud pinnas

Dets. Jaan. Veebr. Märts Aprill Mai Dets. Jaan. Veebr, Märts Aprill Mai

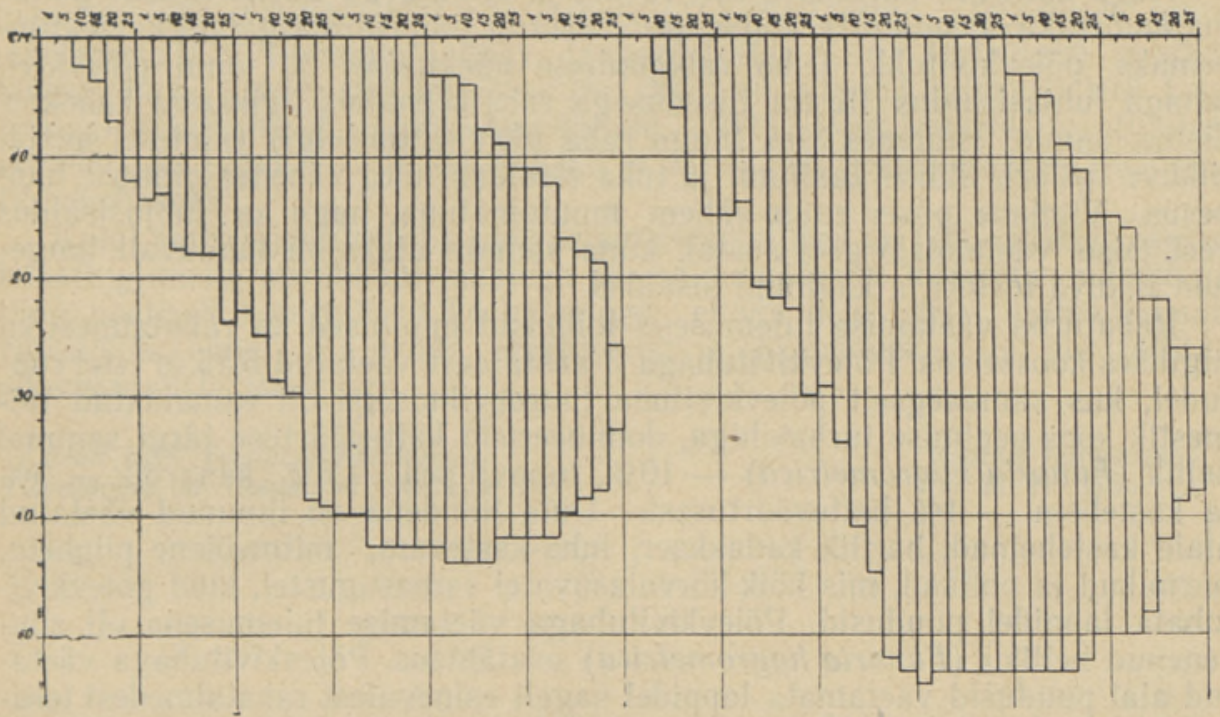

Joon. 3. Rae raba külmumine ja sulamine 1953/54, aastal. 
seetõttu, et taimestiku taastumine toimub kamarast kooritud rabamullal aeglaselt. Rae raba vaatlused näitasid, et kooritud $6,25 \mathrm{~m}^{2}$ suurustel ruudukujulistel lappidel taastus taimestiku endisest katteväärtusest 3 aasta jooksul kuni $1 / 4$. Taimestiku konkurentsiga võimaldubki seletada asjaolu, miks Rae rabal muude võrdsete tingimuste juures $6,25 \mathrm{~m}^{2}$ suurustel ruutudena kamarast kooritud lappidel metsakultiveerimise tulemused osutusid paremaks (puude kõrgus suurem ja väljalangevus väiksem) kui tihedast taimkattest ümbritsetud ja taimejuurtest läbipõimitud $0,25 \mathrm{~m}^{2}$ suurustel ruudukujulistel lappidel (tabel 4).

3-aastased männikultuurid $6,25 \mathrm{~m}^{2}$-stel ja $0,25 \mathrm{~m}^{2}$-stel

Tabel 4 kamarast kooritud lappidel

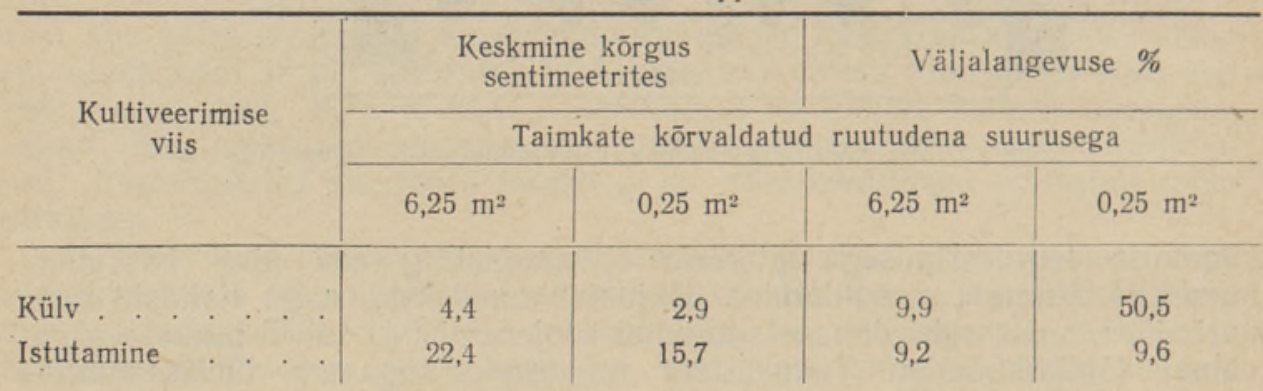

Kuid ülepõletatud, kuivendatud rabapinnas, kus maa on nõuete kohaselt haritud, ei võimalda veel lagerabadel edukat metsakasvatamist. Ilmtingimata vajalik on turba väetamine, mida tavaliselt teostatakse lubjastamise teel (Sukatšov, 1926; Tacke, 1929; Guillebaud, 1938; Brüne, 1952 jt.). Mõ̃̃duka lubjastamisega seotakse rabapinnases osa huumushappeid, mis võimaldab mikrobioloogilise tegevuse intensiivistumist ja seega ka pealmise turbakihi kõdunemist ning taimedele omastatavate mineralsolsolade (eriti lämmastikühendite) moodustumist. Raba lubjastamise tulemusena suureneb rabaturba viljakus (Heuser, 1927; Tacke, 1929; Gedroitz, 1932; Severdov, 1933; Pjavtšenko, 1954 jt.) ja hukkuvad turbasamblad.

Nagu näitavad uurimised Rae rabast ja kinnitavad Eestis rabade põllumajandusliku kasutamise kogemused, osutub lubjast märgatavialt efektiivsemaks põlevkivituhk. 1 ha rabapinnase väetamisel 30 tonni põlevkivituhaga lubjasisaldus $15 \mathrm{~cm}$ tüsedusega rabaturbakihis ligikaudu kahekordistus; samuti suurenes siin (nagu raba ülepõletamiselgi) esimesel aastal liikuva fosfori, üldise kaaliumi ja tuha sisaldus ning vähenes pinnase happesus. Viimane püsis enam-vähem muutumatuna, nagu ka lubjasisaldus veel. teisel väetamisjärgsel laastal, kuna samaks ajaks oli tunduvalt langenud liikuva fosfori ja kaaliumi sisaldus.

Rabaturba väetamise tulemusena toimusid muutused ka rabataimestiku liigilises koosseisus. Põlevkivituhaga 3 aasta eest väetatud $6,25 \mathrm{~m}^{2}$-stel ruutudel, kus samaaegselt põlevkivituha juurdeviimisega oli eemaldatud taimestik koos pealmise turbakihiga, domineerisid katteväärtuse järgi sammal hellik (Funaria hygrometrica) - 10\%, tuppvillpea - 5\%, kanarbik - 3\% ja kastehein - $1 \%$ katteväärtusest. Uute liikidena on ilmunud väetatud alale kasteheinad, harilik kadakkaer, luha-kastevars, mitmeõiene piiphein, nurmikud ja oblikad, mis kõik kõrvalasuvatel samasugustel, kuid põlevkivituhata lappidel puudusid. Põlevkivituhaga väetamise tulemusena oli suurenenud helliku. (Funaria hygrometrica) osatähtsus. Põlevkivituhaga väetatud alal puudusid väetamata lappidel sageli esinevatest rabataimedest teravalehine turbasammal (Sphagnum acutifolium), ümaralehine huulhein, harilik jõhvikas, Cladonia silvatica. 
Kõik see kinnitab, et põlevkivituhaga väetamise tulemusena toimusid rabapinnases olulised muutused paremusele. Rabale ilmusid esimesed rohttaimed, millistega raba täielikul kattumisel on pool lahingut raba metsastamiseks peetud, nagu märgib W. H. Guillebaud (1938).

Et põlevkivituhaga väetamine soodustab oluliselt metsakultuuride arengut, seda kinnitasid katsed Rae rabal, kus 3-aastased männi-istandused põlevkivituhaga väetatud alal ületasid viimase aasta kõrguse juurdekasvus väetamata aladel asuvaid mände mitmekordselt.

Arvestades rabade põllumajandusliku kasutamise kogemusi ja meie esialgseid tähelepanekuid Rae raba metsastamiskatsetest, võib arvata, et sobivaks põlevkivituhaväetise normiks on ca $15-20$ tonni 1 ha-le, kusjuures tingituna puude pikast kasvuajast ei piisa enne raba kultiveerimist teostatud ühekordsest väetamisest. Missuguste vaheaegade järel ja missugustes annustes tuleb kultiveeritud rabaosa väetamiseks põlevkivituhka kasutada, nõuab veel lahendamist. Esialgsed tähelepanekud lubavad eeldada, et raba ühekordsest väetamisest põlevkivituhaga piisab vähemalt $4-5$ aastaks.

Kergesti pinnasest väljauhutavate mineraalväetiste (superfosfaat, kaalisool) ühekordne kasutamine, samuti ka liiva lisamine andsid meie katsetel vähem tulemusi. Saavutatud metsanduslik efekt jäi sedavõrd tagasihoidlikuks, et see ei tasunud väetamisega seoses olevaid kulusid.

Rabade edukas metsastamine sõltub peale eelkirjeldatud abinõude rakendamise veel otstarbekohase metsakultiveerimisviisi ja sobiva puuliigi valikust. Rae raba katsed näitasid, et ka rabal, nagu see on üldkehtiv kõigil äärmuskasvukohtadel, osutuvad istandused külvidest märksa tulemuskindlamaks. Siin 3 laasta vanustes katsekultuurides oli külvides keskmine väljalangevus 30\% (kohati isegi üle 50\%), kuna istandustes ulatus see $6 \%$-ni.

Kultiveeritava puuliigina tuleks meie oludes eelistada harilikku mändi. Katsetada võiks ka hariliku kuuse kultiveerimist. Meie tähelepanekute kohaselt võib kuusk saavutada rabal mõne meetri kõrguse; ta kasvab noores eas hästi Rootsis puutuhaga väetatud raba osadel (Malmström, 1952). Samuti on põhjendatud katsetamine murrei männiga (Pinus Murrayana), mille kasvatamine rabadel on andnud häid tulemusi Inglismaal (Guillebaud, 1938; Macdonald, 1951; Zehetmayr, 1953) ja mida leidub rabastuviatel aladel üksikute hästi arenenud puudena ka meil. Samuti vääriks katsetamist veel kase ja dahuuria lehise (Larix dahurica) kasvatamine. Viimasele juhib tähelepanu V. V. Romanov (1953). Jaapani lehise (Larix leptolepis) ja sitka kuuse (Picea sitchensis) kasvatamine rabal on andnud tulemusi küll Inglismaal (Guillebaud, 1938; Macdonald, 1951), kuid makroklimaatilistest erinevustest põhjustatuna tõenäoliselt ei osutu nende kasvatamine meil otstarbekohaseks.

Kuigi eelkirjeldatud raba metsastamisvõimalused on põhjendatud kasvukohatingimuste uurimistulemustega ja usaldusväärsete kirjandusandmetega ning osaliselt kontrollitud ka katsetega, ei või neid siiski ulatuslikumalt rakendada enne, kui nende efektiivsust ja ökonoomsust on kontrollitud pikemaajaliste katsetega. 


\section{KIRJANDUS}

Becker-Dillingen, 1939. Die Ernährung des Waldes. Verlagsgesellschaft für Ackerbau $\mathrm{mbH}$.

B r ü ne, Fr., 1952. Fortschritte in der Bewirtschaftung von Hochmoor und Heidesandböden. Zeitschrift für Pflanzenernährung, Düngung, Bodenkunde. Band 58 (103), Heft 3.

B ü low, K., 1929. Handbuch der Moorkunde. Allgemeine Moorgeologie. Einführung in das Gesamtgebiet der Moorkunde. Berlin.

G uille ba ud, W. H., 1938. The Afforestation of Difficult Peat and Upland-Heath Soils. Forestry. Vol. XII, No 2. Humphrey Milford, London.

Franz, H., 1950. Bodenzoologie als Grundlage der Bodenpflege. Akademie-Verlag. Berlin.

H e u ser, O., 1927. Grundriss der Moorkultur. Berlin und Leipzig.

$\mathrm{K}$ a r u, A., 1938. Mõnda Luunja valla «Kangro» talust ja ta metsandusest. «Eesti Mets» nr. 4 .

Kollist, P., 1953. Kuivendamise mõju üleminekusoometsade uuenemistingimustele. Loodusuurijate Seltsi juubelikoguteos. Tallinn.

Macd onald, J. A. B., 1951. Plantations of Peatlands. Report on Forest Research for the Year Ending. London.

Ma lmströ m, C., 1952. Svenska gödslingsförsök för belysande av de näringsekologiska villkoren för skogsväxt på torvmark. Metsätieteellisen Tutkimuslaitoksen Julkaisuja 40. Helsinki.

Markus, R., 1940. Die Aufforstung von Hochmooren und Dünen, Ref. Jahrbuch der Moorkunde. 27. Jahrgang 1939. Hannover.

Mult a mäk i, S. E., 1952. Suo metsän kasvupaikana. Metsätieteellisen Tutkimuslaitoksen Julkaisuja 40. Helsinki.

S e el horst, C., 1914. Handbuch der Moorkultur, 2. Auflage. Berlin.

$\mathrm{T}$ a ck e, B., 1929. Die naturwissenschaftlichen Grundlagen der Moorkultur. Die neuzeitliche Moorkultur in Einzeldarstellungen. Herausgegeben vom Verein zur Förderung der Moorkultur im Deutschen Reiche. Heft 1. Berlin.

V a 1 k, U., 1953. Kogemusi nõmmealade metsastamisel. - Eesti NSV fauna ja floora uurimise küsimusi. Tallinn.

V a r e p, E., 1953. Eesti NSV lääneosa soode geobotaaniline iseloomustus. - Eesti NSV fauna ja floora uurimise küsimusi. Tallinn.

$Z$ ehet mayr, J. W., 1953. Problems of Moorland Afforestation. Quarterly Journal of Forestry. Vol. XLVII, No. 1.

Ани ки е в В. В., Обухов а Г. А. и др., 1951. Летние практические занятия по физиологии растений. Ленинград-Москва.

Ба хулин М. Д., 1949. Агрономическая характеристика торфа. К вопросу освоения и развития производительных сил Полесья. Минск.

Беляков а В. И., 1954. Выращивание овощей на торфяных почвах. МоскваЛенинград.

В и ле н с ки й Д. Г., 1954. Почвоведение. Москва.

Г а р к уша И. Ф., 1947. Болотные почвы и пути их использования. Изд. Белорусского ордена трудового красного знамени сельскохоз. института.

Г е д р о й ц К. К., 1932. Химический анализ почвы. Издание 3-е. Москва-Ленинград.

Гу ле й чик К. А., 1954. Севообороты на торфяно-болотных почвах. Минск.

Д ок ту ров ски й В. С., 1935. Торфяные болота. Происхождение, природа и особенности болот СССР. 2-ое дополненное издание. Москва-Ленинград.

Д о кукин М. В., 1939. Освоение болот под сельскохозяйственные культуры. Осушение и освоение болот. Материалы VII пленума секции гидротехники и мелиорации от 4-8 июля 1938 г. ВАСХНИЛХ, Москва.

Д у б а х А. Д., 1945. Гидротехнические мелиорации лесных земель. Москва.

3 а й ц е в Б. А., 1954. Об осушении заболоченных почв в условиях лесного хозяйства. « Лесное хозяйство» № 9.

Коз ло в К. А., 1955. Наблюдение за микрофлорой торфяно-болотных почв при их известкованин. Автореферат. Ленинградский ордена Ленина Гос. университет имени А. А. Жданова.

К ост я ков А. Н.,- 1951. Основы мелиораций. Москва.

Л у пи но ви ч И. С. и Гол уб Т. Ф., 1952. Торфяно-болотные почвы БССР и их плодородие. Минск. 
Н е м чи нов А. А., 1953. ББолотные почвы и их использование. Москва-Л̈енингра́ді.

П ь я в ч е н ко Н. И., 1954. Использование заболоченных земель в сельском хозяйстве. Москва.

Р ом ано в В. В., 1953. Исследование испарения со сфагновых болот. Труды Гос. гидр. инст., вып. 39.

С у к а ч е в В. Н., 1926. Болота, их образование, развитие и свойства. Третье дополнен. и иллюстрир. изд. Ленинград.

Т а н фи лье в Г. И., 1895. Болота и торфяники Полесья. С. Петербург.

Т у рн а с П. А., 1936. Поверхностный обжиг болот и влияние его на условия плодородия торфяных почв. «Химизация соц. земледелия» № 6.

Ш ев ердов П. И., 1933. Культура болот. Москва-Смоленск.

\title{
О ПРОБЛЕМЕ ОБЛЕСЕНИЯ БЕЗЛЕСНЫХ ВЕРХОВЫХ БОЛОТ
}

\author{
У. А. ВАЛК, \\ кандидат биологических наук
}

Резюме

Примерно 17 процентов площади Әстонской ССР занято болотами, причем от одной трети до половины из них составляют верховые болота.

Несмотря на широкое распространение верховых болот в природном ландшафте республики, они до настоящего времени все еще мало используются в народном хозяйстве, особенно в растениеводстве.

Использование верховых болот в качестве сельскохозяйственных угодий затрудняется чрезвычайно неблагоприятными условиями роста растений. Разведение культурных растений на глубоко-торфяных верховых болотах мыслимо только при радикальном изменении господствующих там условий. Возможность такого преобразования подтверждается многолетним опытом сельскохозяйственного освоения верховых болот за границей и опытом последних лет в Эстонской ССР.

При длительном сельскохозяйственном использовании болот в них (особенно в пахотном слое) образуются новые условия, создающие предпосылки для выращивания леса. Проведенные нами в Калининградской области наблюдения показывают, что прежние верховые болота, использованные в сельском хозяйстве, покрылись со временем березой, рост которой до сих пор (до 10-15 лет) протекает удовлетворительно.

K сожалению, облесение безлесных глубоко-торфяных верховых болот с предварительным сельскохозяйственным использованием является сложным и весьма дорогостоящим приемом, в связи с чем для их облесения необходимо найти какие-нибудь другие более дешевые и экономные способы.

При изыскании способов облесения глубоко-торфяных безлесных верховых болот исходили из того, что их нельзя облесить до того времени, пока не создан более благоприятный для роста растений гидрологический режим и не повышено содержание питательных веществ в болотной почве (причем должно быть обеспечено их удерживание на одном уровне без ежегодного удобрения), а также пока не прекращается быстрое нарастание органической массы (особенно сфагновых мхов).

Опыт показывает, что одной предпосылкой облесения глубоко-торфяных верховых болот является интенсивное осушение, проведенное таким образом, чтобы подлежащий облесению участок полностью находился в пределах влияния осушения. 
Оิпыты, проведенные за границей, показывают, что для облесения наиболее целесообразно создать на верховых болотах сеть мелких (вырытых вручную или при помощи специального плуга) канавок, направленных в обычные открытые осушительные канавы. При применении ручного труда наиболее экономная ширина и глубина канавок составляет 35-40 см, а расстояние между ними 4-6 м. Между канавками создаются грядки.

Для успешного облесения необходимо также уменьшить кислотность торфа. Как показали опытные культуры, заложенные на Раэском верховом болоте (вблизи Таллина), в наших условиях с этой целью целесообразно применять сланцевую золу, которую в Әстонии легко достать. При внесении сланцевой золы в верховое болото значительно повышалось содержание извести, подвижного фосфора и валового калия, а кислотность уменьшалась. На удобренной сланцевой золой почве 3-летние саженцы сосны показали хороший рост, и прирост их достиг в последний год в среднем $15 \mathrm{~cm}$.

Опыты на Раэском верховом болоте показали еще, что посадки дают более надежные результаты, чем посевы.

Наиболее подходящей породой для культивирования верховых болот является в наших условиях сосна обыкновенная. Также обосновано проведение опытов с сосной Муррея, разведение которой на заболоченной почве давало у нас хорошие результаты. Опыты следовало бы провести также и с елью, березой и лиственницей даурской.

Более продолжительные опыты должны показать эффективность и экономичность описанных способов облесения глубоко-торфяных верховых болот.

Институт зоологии и ботаники Академии наук Эстонской ССР

Поступила в редакцию 20 IV 1956

\section{ON THE PROBLEM OF AFFORESTING TREELESS BOGS}

\section{U. VALK}

\section{Summary}

Of the total area of the Estonian SSR about 17\% are covered with marshes and it can be assumed that from a quarter to a half of the Estonian marshes are of the peat-bog category.

In spite of the extensive occurence of bogs in natural landscapes they have until now found but little utilization in national economy (especially in plant cultivation).

Treeless bogs have been little utilized in plant cultivation because they offer unfavourable conditions for plant growth. The utilization of treeless bogs is conceivable only when the site factors prevailing there have been fundamentally changed for those more favourable to plant growth. That this is possible has been confirmed by the experience of utilizing bogs for agricultural purposes also in the Estonian SSR.

As a result of prolonged agricultural utilization there are formed on the bogs new site factors which after prevailing for a considerable period also 
prepare the ground for forest growth. As our observations in the Kaliningrad region of the RSFSR show, former bogs which have been in agricultural use have been covered with a birch forest of natural growth, the growth of which forest up to now (to the age of $10-15$ years) has been satisfactory.

Unfortunately the afforestation of treeless bogs by means of previous agricultural utilization proves complicated and costly, why it is necessary to find other more simple and more economical ways.

Previous experience shows that the afforestation of deeppeat treeless bogs has for its precondition an intensive draining of slightly burnt-out bog, in consequence of which the tract to be afforested remains as a whole in the sphere of influence of the drainage. On the drained tract of bog it is necessary to lower the acidity of the peat, which at the same time checks the growth of the sphagnum. As the experimental cultures instituted on the Rae bog near Tallinn show, it is expedient in our country to use the ashes of oilshale, which is not difficult to procure in the Estonian SSR. As a result of manuring with oil-shale ashes the content of lime, potassium and shifting phosphorus in the bog soil was increased and the acidity of the peat decreased. On the area manured with oil-shale ashes a three-year old Scotch-pine plantation of good growth aspect reached an average last year height increment of $15 \mathrm{~cm}$. Cultivation by sowing gave more casual results.

The efficiency and economy of the ways of afforesting deeppeat bogs is to be controlled by experiments of longer duration.

Academy of Sciences of the Estonian SSR,

Received Institute of Zoology and Botany 